\title{
Myophosphorylase deficiency (McArdle's disease) in two interrelated families
}

\author{
P. COCHRANE, R. R. HUGHES, P. H. BUXTON, AND R. A. YORKE \\ From the Royal Southern and Walton Hospitals, Liverpool
}

\begin{abstract}
SUMMARY The clinical and laboratory findings are presented of three patients (two affected sisters and their male cousin) with myophosphorylase deficiency in two interrelated families. Nine unaffected relatives were also investigated. Although the three patients demonstrated the characteristic features of the disease, their unaffected relatives showed no clear evidence of a heterozygous state. The genetic findings support the hypothesis that the disease is inherited as a rare autosomal recessive. A possible sex-limited mode of inheritance is discussed.
\end{abstract}

In 1951 McArdle described a 30 year old male who had complained of painful muscular cramps on exercise from early childhood. A defect in the breakdown of muscle glycogen was suspected when the serum lactate and pyruvate failed to rise in blood flowing from ischaemic muscle after exercise. It was not until 1959 that Mommaerts, Illingworth, Pearson, Guillory, and Seraydatian, and Schmid and Mahler independently established the metabolic defect of this myopathy. Examination of muscle biopsy material showed an excessive glycogen content and myophosphorylase activity was absent.

Several studies of affected families have suggested that the disorder is a recessive character shown by individuals homozygous for a rare autosomal gene. The present study describes a further three related patients with this rare inherited myopathy. In addition, nine unaffected relatives were investigated in an attempt to identify the heterozygous state.

\section{GENETIC ASPECTS}

The family pedigree is illustrated in Fig. 1. The families live in a remote area of North Wales where intermarriage is not uncommon. The two affected families in the present sixth generation share common ancestors. Two aff $c$ cted sisters, the proposita VI, 8 (case 1), and VI, 10 (case 2) are first cousins to an affected male VI, 11 (case 3), as their mothers V, 1 and 2 (cases 4 and 8) and father IV, 7 and 8 (cases 5 and 7), are sisters and brothers respectively. Each parent had married their distant cousin. The grandmother, III, 2 (case 12) of the affected sisters had married twice. Her second husband III, 3 was second cousin to the grandparents IV, 12 and 13 of the affected male. These grandparents were also first cousins. The second generation was not fully traced. In the present study three affected patients VI, 8, 10, and 11 (cases 1,2 , and 3 ) and nine unaffected relatives, III, 2; IV, 6, 7, and 8; V, 1 and 2; VI, 9, 12, and 13 (cases 4-12) were investigated. Most members of the fourth, fifth, and sixth generations who were not examined, were questioned, and none complained of muscle symptoms.

\section{CLINICAL METHODS}

The following investigations were performed: haemoglobin, full blood count, blood urea and serum electrolytes, urinary myoglobin (after exercise), serum proteins and electrophoretic pattern, blood sugar, liver function tests, radiographs of the chest, and electrocardiography both before and after exercise, serum glutamic oxaloacetic and pyruvate transaminases (SGOT and SGPT) (Karmen, Wroblewski, and Ladue, 1955), lactic acid dehydrogenase (LDH) (King, 1959), aldolase and creatine phosphokinase (estimated by kit methods No. 750 and 661 respectively, provided by Sigma Chemical Company, St. Louis, U.S.A.), and plasma lactate (Barker and Summerson, 1941) after ischaemic muscle exercise (McArdle, 1951). Doctors and medical students acted as controls when a patient or group of patients were tested. 


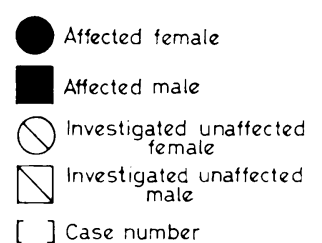

[ ] Case number

Proposita
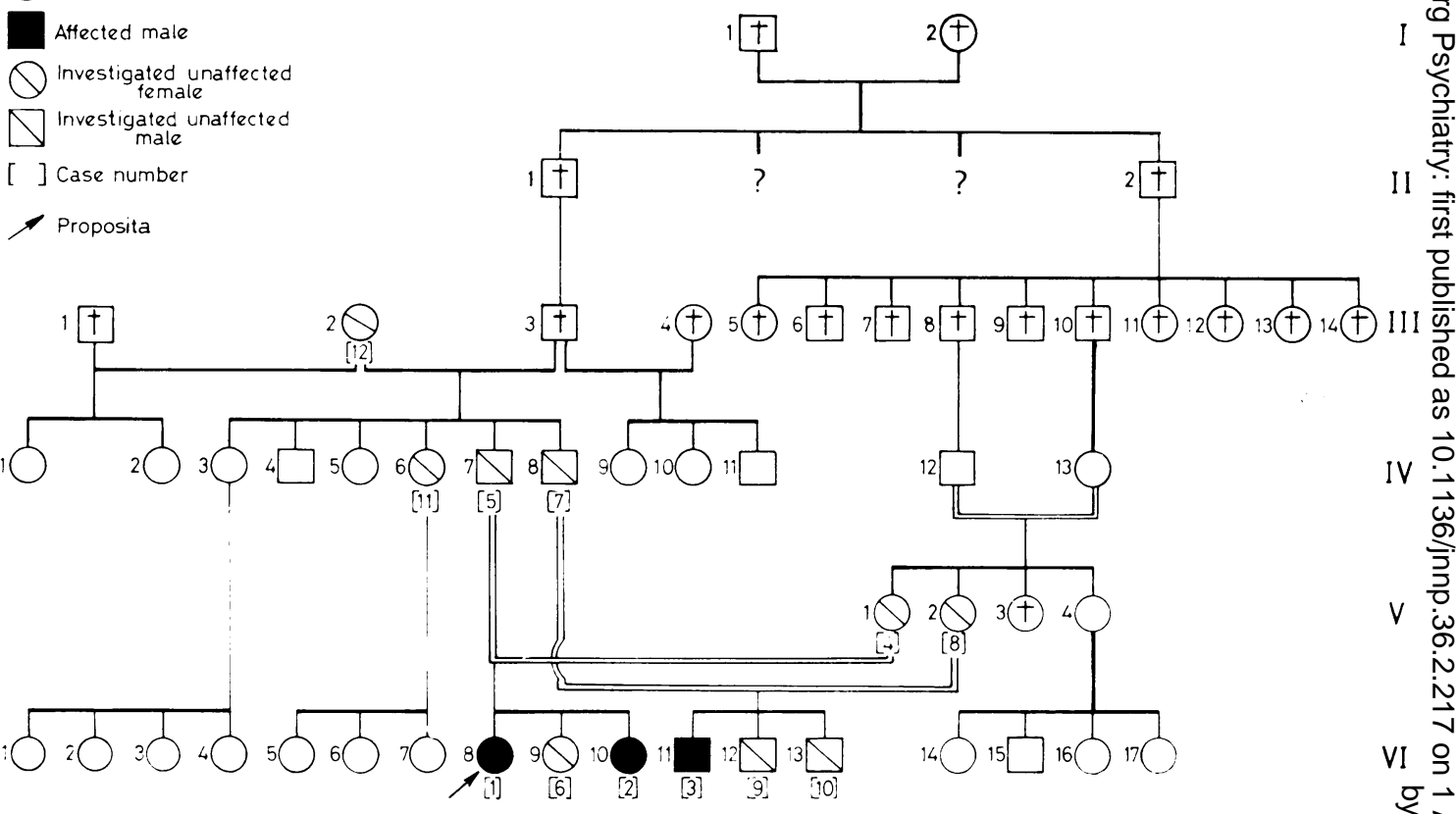

FIG. 1. The pedigree of two interrelated families affected by myophosphorylase deficiency (McArdle's disease.

ELECTROENCEPHALOGRAPHY A standard eight channel electroencephalogram was performed.

ELECTROMYOGRAPHY Electromyograms were recorded from the right flexor digiti minimi and flexor digitorum sublimis muscles using concentric needle electrodes.

An attempt was made to induce a 'contracture' by asking the patients to alternately grip and relax their hand, with the blood supply occluded by a sphygomanometer cuff around the upper arm inflated to 150-160 mm mercury for 10 minutes. A sustained electrically silent 'contracture' has been described as a characteristic feature of this condition (McArdle, 1951).

The screening test described by Dyken, Smith, and Peake (1967) was also utilized. This involves the repetitive stimulation of the ulnar nerve with supramaximal stimuli at a rate of $18 / \mathrm{sec}$, and recording from the abductor digiti minimi muscle by a concentric needle electrode, and is thought to produce a considerable $(75 \%)$ drop in the amplitude of the evoked response over a $100 \mathrm{sec}$ period in an affected individual. This procedure may also produce an electrically silent 'contracture' in an affected patient.

Muscle biopsy was performed on two affected patients, cases 1 and 3, and one normal subject, case
4. Biochemical analysis of the glycogen content (O'Brien and Ibbott, 1962) and myophosphorylase activity (Sutherland and Wosilait, 1956) were performed by Dr. H. G. Badman and Mrs. S. Simpson (Department of Chemical Pathology, United Liverpool Hospitals). The other affected patient, case 2, refused muscle biopsy.

\section{CASE 1}

The proposita, a 19 year old female, had complained of muscular weakness and cramps for 'as long as she could remember'. As a young child she had pre- 0 ferred to be carried after walking short distances, and was unable to keep pace with her parents. She had avoided games at school and found difficulty in skipping and climbing stairs. Her symptoms varied $\mathrm{O}$ from day to day. She experienced leg symptoms after $\square$ walking only several hundred yards, and had fallen on several occasions when she had attempted to continue. After a short rest she was often able to walk a O longer distance without symptoms than before-that $N$ is, she experienced a 'second wind phenomenon'. N She might take an hour to recover from the generalo fatigue of a 10 minute walk. Occasional symptoms were also experienced in her jaws while chewing, and in her upper limb muscles when mixing cakes. She 
had never passed dark urine. At one time her symptoms had been thought to be psychiatric in origin.

Clinical examination was normal, but it was noted that the calf and thigh muscles were particularly well developed. No muscular wasting was apparent. Repetitive exercise of her lower limb muscles on steps produced the typical muscular symptoms.

The results of the relevant investigations were as follows: serum aldolase, $23 \mathrm{~S}-\mathrm{L}$ u./ml. (normal $<12$ ); serum creatine phosphokinase 83 sigma u./ml. (normal <20); SGOT $55 \mathrm{u} . / \mathrm{ml}$. (normal 540); SGPT 15 u./ml. (normal 3-35); LDH 700 u./ml. (normal 200-450); urine-no myoglobin. The plasma lactate test showed no rise (Fig. 2). Electrocardiography was normal. Electroencephalography showed an irregular $10 \mathrm{~Hz}$ alpha rhythm and occasional spikes after hyperventilation.

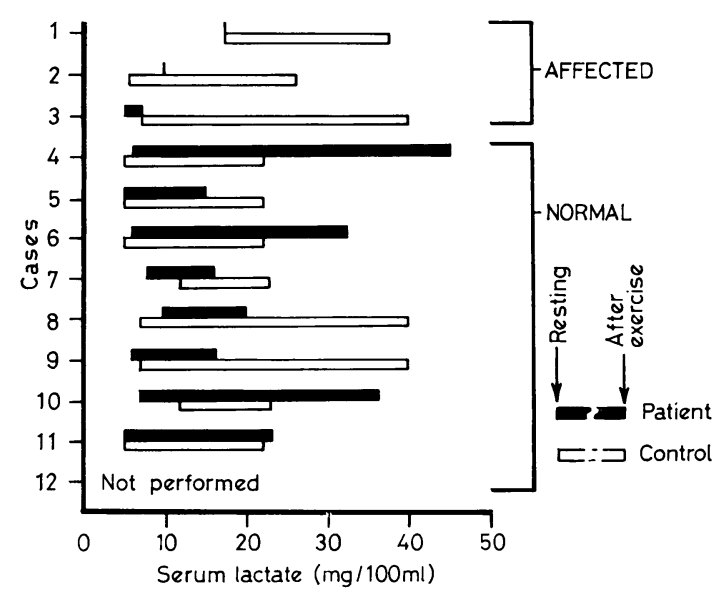

FIG. 2. Increase in serum lactate after ischaemic exercise (McArdle, 1951) in 12 subjects.

ELECTROMYOGRAPHY Recordings from the forearm muscles were normal. An attempt to induce a 'contracture' by ischaemic exercise was unsuccessful and the patient was able to use her hand normally immediately after the cuff was released. Repetitive stimulation of the ulnar nerve produced a $75 \%$ drop in the amplitude of the evoked response. This procedure also did not produce an electrically silent 'contracture'.

MUSCLE BIOPSY AND HISTOCHEMISTRY Microscopy Conventional stains showed occasional eosinophilic muscle fibres, some of which had central pyknotic nuclei. In longitudinal section a few fibres showed floccular change and, in a few, striations were indistinct. Interstitial tissue, blood vessels, and nerves appeared normal.

Frozen sections Stains for glycogen showed some general excess, as against a normal control, and on the periphery of some fibres, sometimes within, and more often outside the sarcolemmal sheath, were collections of homogeneous material staining for glycogen. Digestion by amylase confirmed that this material was glycogen.

Muscle enzymes There was a complete absence of myophosphorylase as shown by histochemical staining technique but TPN and DPN diaphorases still showed the normal chequered staining pattern. Cholinesterase staining showed mostly well-defined terminal expansions, though some were distorted and poorly stained. Staining took slightly longer than usual. Intravital methylene blue staining showed some irregularity of terminal expansions of motor nerve fibres some of which appeared rather distended, and some terminal nerve fibres showed slight varicosities. However some normal terminal innervation was seen.

Biochemical analysis of muscle No myophosphorylase activity was found, whereas a control rat muscle gave a normal assay. The glycogen content was $3 \cdot 2$ $\mathrm{g} / 1 \mathrm{c0} \mathrm{g}$ fresh muscle, the normal range being $0 \cdot 2$ $0.9 \mathrm{~g} / 100 \mathrm{~g}$.

CONCLUSION The absent myophosphorylase, the increase in glycogen, and mild muscle fibre change are diagnostic of myophosphorylase deficiency.

TREATMENT Both glucose and fructose taken orally before exercise eased her symptoms. However, she discontinued this treatment because of weight gain.

\section{CASE 2}

She was the 15 year old sister of the proposita. This schoolgirl had complained of muscular cramps on marked exertion since early childhood. Her symptoms were aggravated by running for long distances, but she could run for a bus, ride a bicycle, and run upstairs without symptoms. When playing hockey she preferred a defensive rather than an attacking position, which might aggravate symptoms. The intensity of her symptoms varied from day to day, but did not appear to be progressing. She had never passed dark urine.

She was of athletic build and no muscular wasting 
was apparent. During the ischaemic lactate test she experienced painful flexion spasms of the hand, which persisted for several minutes after the cuff had been released.

The results of the relevant investigations are as follows: serum enzymes-serum aldolase $23 \mathrm{~S}-\mathrm{L}$ u./ml.; serum creatine phosphokinase 41 sigma units; SGOT 25 u./ml.; SGPT 39 u./ml.; LDH 250 $\mathrm{u} . / \mathrm{ml}$. Urine-no myoglobin. The plasma lactate test showed a minimal rise (Fig. 2). Electrocardiogram was normal. Electroencephalography showed a $9 \mathrm{~Hz}$ alpha rhythm together with a fair amount of slow activity in the delta and theta ranges.

ELECTROMYOGRAPHY The record from a forearm muscle was normal. No contracture was induced by ischaemic exercise. The repetitive stimulation test produced a $68 \%$ reduction in the amplitude of the evoked potential. Muscle biopsy was refused.

TREATMENT Glucose taken before exercise relieved her symptoms to some extent.

\section{CASE 3}

He was a first cousin of the proposita. This 17 year old farm worker had experienced weakness and stiffness in his limb muscles on exertion since early childhood. The milestones of infancy had been normal, but his parents had noticed that he had walked awkwardly since the age of 3 . He had avoided games at school. Leg symptoms were aggravated by walking up several flights of stairs and he was unable to ride a bicycle. His symptoms were most marked in the mornings when he went immediately from his bed to work on the farm. They appeared less troublesome from mid-day, and he avoided symptoms by gradually increasing his activity. $\mathrm{He}$ was able to perform less strenuous tasks such as tractor driving without symptoms, whereas tossing hay would aggravate symptoms in his upper limbs.

Medical advice had not been sought, as his parents had considered that his condition, like that of his cousins, was untreatable.

He was of muscular build and clinically normal.

The results of the relevant investigations were as $\overrightarrow{\vec{\omega}}$ follows: serum enzymes-serum aldolase $15 \mathrm{~S}-\mathrm{L}$. u./ml.; serum creatine phosphokinase 41 sigma u./ml.; SGOT 7 u./ml.; SGPT 81 u./ml.; LDH $150 \mathrm{u} . / \mathrm{ml}$. The ischaemic lactate test showed a $\omega^{\circ}$ minimal rise (Fig. 2). Urine-no myoglobin. N Electrocardiography was normal. Electroencephalography showed a $9 \mathrm{~Hz}$ alpha rhythm together with a 0 considerable amount of slow activity within the delta and theta ranges.

ELECTROMYOGRAPHY Recordings from the hyp thenar muscles were normal, and no electricalb $\vec{\omega}$ silent 'contractures' were noted. The decrement $\underset{\mathbf{n}}{\mathrm{m}} \mathrm{\omega}$

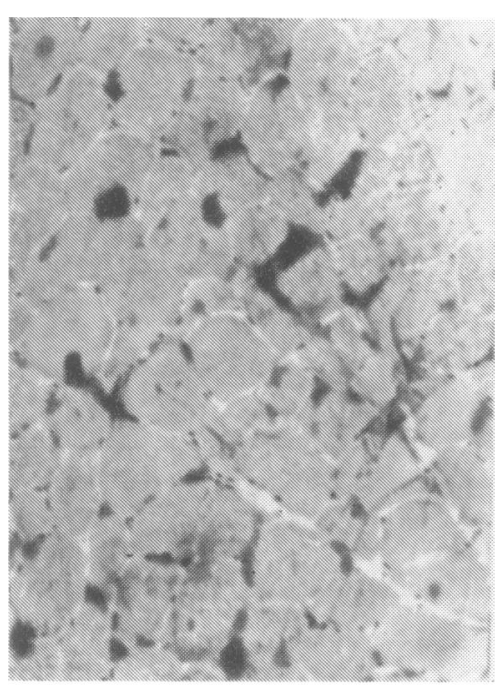

(a)

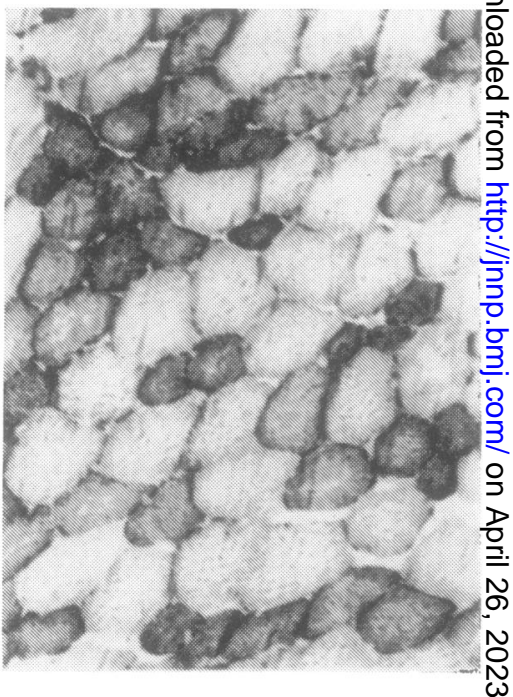

(c)

FIG. 3. Photomicrographs of case 3, an affected patient with myophosphorylase deficiency. (a) Stained for $\stackrel{\bullet}{\complement}$ $D P N$ diaphorase. (b) Stained for phosphorylase. (c) Best's carmine stain for glycogen. 
the amplitude of the evoked potential on repetitive ulnar nerve stimulation was $50 \%$.

MUSCLE BIOPSY AND HISTOCHEMISTRY Microscopy Conventional stains showed some variation in muscle fibre size and occasional areas compatible with subsarcolemmal vacuolation, particularly in the longitudinal sections. Blood vessels and connective tissue appeared normal.

Muscle enzymes TPN and DPN diaphorases (Fig. 3a) showed normal chequered distribution pattern. Myophosphorylase (Fig. 3b) was completely absent. Glycogen staining (Fig. 3c) showed an excess, mainly in blebs under the sarcolemmal sheath and occasionally outside the sheath. Intravital methylene blue showed no gross abnormality of motor nerve endings, although some branching in preterminal nerve fibres was seen, with occasional beaded fibres. Biochemical analysis of muscle: glycogen $1.53 \mathrm{~g} / 100 \mathrm{~g}$ (control muscle $1.09 \mathrm{~g} / 100 \mathrm{~g}$ ). Phosphorylase-no activity detected (control rat muscle $120.5 \mu-\mathrm{mole} / \mathrm{min} / \mathrm{g}$, human control $96.5 \mu$-mole/ $\mathrm{min} / \mathrm{g}$ ).

CONCLUSION The most striking features were the absence of myophosphorylase and increase of glycogen. These features are diagnostic of myophosphorylase deficiency. The slight innervation changes were probably secondary.

TREATMENT Oral glucose relieved his muscular symptoms to some extent. A trial of fenfluramine (Ponderax, kindly supplied by Servier Labs Ltd, Harrow, Middx.) was made. This drug is used in the treatment of obesity and is thought to increase glucose uptake into muscle cells; $20 \mathrm{mg}$ t.d.s. was given for four weeks, but no benefit was noted, and no significant weight loss occurred.

\section{CASE 4}

The unaffected 37 year old mother of cases 1 and 2 . She had recently complained of tiredness on exertion, and had also experienced difficulty in climbing stairs due to low back pain. Clinically her symptoms were thought to be due to osteoarthritis of the lumbar spine, aggravated by obesity. A radiograph of the lumbar spine confirmed the diagnosis.

The results of the relevant investigations were as follows: serum enzymes-serum aldolase $10 \mathrm{~S}-\mathrm{L}$ u./ml.; serum creatine phosphokinase 2 sigma u. $/ \mathrm{ml}$.; SGOT 10 u./ml.; SGPT $10 \mathrm{u} . / \mathrm{ml}$.; LDH $200 \mathrm{u} . / \mathrm{ml}$. Urine-no myoglobin. The plasma lactate test showed a normal rise (Fig. 2). Electrocardiography was normal. Electroencephalography showed an irregular $8 \mathrm{~Hz}$ alpha rhythm with some theta activity and occasional bursts of spikes during hyperventilation.

ELECTROMYOGRAPHY Records from hypothenar muscles were normal; no 'contracture' was detected. There was no decrement in the amplitude of the evoked muscle potential on repetitive stimulation of the ulnar nerve.

MUSCLE BIOPSY AND HISTOCHEMISTRY Microscopy Conventional stains showed some variation in muscle fibre size, but no significant small fibre groups, or dystrophic type fibres. Blood vessels and connective tissue showed no abnormality.

Muscle enzymes Myophosphorylase and diaphorase showed normal complementary staining pattern. Glycogen staining was within normal limits. Intravital methylene blue staining showed some normal nerve fibres and end plates, but there was significant terminal and preterminal branching of fibres and pleomorphism of the end plates.

Biochemical analysis of muscle Glycogen $0.44 \mathrm{~g} /$ $100 \mathrm{~g}$ (control rat muscle $1.09 \mathrm{~g} / 100 \mathrm{~g}$ ). Phosphorylase $37.9 \mu-\mathrm{mole} / \mathrm{min} / \mathrm{g}$ (control rat muscle 120.5 $\mu$-mole $/ \mathrm{min} / \mathrm{g}$, human control $96.5 \mu$-mole $/ \mathrm{min} / \mathrm{g}$ ).

CONCLUSION The muscle biopsy appearances suggest some denervation change. There was no evidence of myophosphorylase deficiency.

The eight other members of the families investigated showed no evidence of muscle disease (Fig. 2 and Table). Electromyographic investigation revealed normal records, and no silent 'contractures' were produced by ischaemic exercise. Repetitive maximal ulnar nerve stimulation produced less than $50 \%$ decrement in the evoked response in all subjects apart from case 9 who had a $69 \%$ fall. Dyken's test did not, therefore, clearly distinguish between the normal and affected cases. Several members of the families showed abnormal electroencephalograms irrespective of muscle disease. The abnormal features were excessive slow frequency activity within the delta and theta ranges. The proposita showed occasional spike formation. The slow activity in case 12 presumably reflected cerebral arteriosclerosis. Serum enzyme studies (Table) were normal in six of the eight apparently unaffected individuals. Two persons had slightly raised SGPT values, which are unexplained. 
TABLE

NUMERICAL DATA ON PATIENTS AND UNAFFECTED RELATIVES IN TWO INTER-RELATED FAMILIES WITH MYOPHOSPHORYLASE DEFICIENCY

\begin{tabular}{|c|c|c|c|c|c|c|c|c|c|c|c|c|c|}
\hline & & \multicolumn{12}{|c|}{ Case } \\
\hline & & 1 & 2 & 3 & 4 & 5 & 7 & 8 & 6 & 9 & 10 & 11 & 12 \\
\hline Genetic status & & \multicolumn{3}{|c|}{ Homozygous } & \multicolumn{4}{|c|}{ Heterozygous } & \multicolumn{5}{|c|}{ Unknown } \\
\hline Clinical status & & \multicolumn{3}{|c|}{ Affected } & \multicolumn{8}{|c|}{ Unaffected } & \\
\hline \multicolumn{2}{|c|}{$\begin{array}{l}\text { Serum lactate rise (before and } \\
\text { after ischaemic exercise) }\end{array}$} & $0\left\{\begin{array}{l}17.5 \\
17.5\end{array}\right.$ & $0.3\left\{\begin{array}{l}10 \cdot 2 \\
10.5\end{array}\right.$ & $2\left\{\begin{array}{l}5 \\
7\end{array}\right.$ & $39\left\{\begin{array}{r}6 \\
45\end{array}\right.$ & $10\left\{\begin{array}{r}5 \\
10\end{array}\right.$ & $8\left\{\begin{array}{r}8 \\
16\end{array}\right.$ & $10\left\{\begin{array}{l}10 \\
20\end{array}\right.$ & $26\left\{\begin{array}{r}6 \\
32\end{array}\right.$ & $10\left\{\begin{array}{r}6 \\
16\end{array}\right.$ & $29\left\{\begin{array}{r}7 \\
36\end{array}\right.$ & $18\left\{\begin{array}{r}5 \\
23\end{array}\right.$ & - \\
\hline Serum enzymes & $\begin{array}{l}\text { Normal } \\
\text { range }\end{array}$ & & & & & & & & & & & & \\
\hline $\begin{array}{l}\text { Aldolase } \\
\text { Creatine }\end{array}$ & $<12 u$ & 23 & 23 & 15 & 10 & 12 & 3 & 3 & 10 & 12 & - & 5 & 5 \\
\hline $\begin{array}{l}\text { phosphokinase } \\
\text { SGOT }\end{array}$ & $\begin{array}{l}<20 \mathrm{u} . \\
5-40 \mathrm{u}\end{array}$ & $\begin{array}{l}83 \\
55\end{array}$ & $\begin{array}{l}41 \\
25\end{array}$ & $\begin{array}{r}41 \\
7\end{array}$ & 10 & 25 & $\begin{array}{l}2 \\
4\end{array}$ & 5 & $\begin{array}{r}18 \\
7\end{array}$ & $\begin{array}{l}18 \\
25\end{array}$ & $\begin{array}{l}5 \\
7\end{array}$ & $\begin{array}{r}3 \\
25\end{array}$ & $\begin{array}{r}3 \\
17\end{array}$ \\
\hline SGPT & $5-35$ u. & 15 & 39 & 81 & 10 & 20 & 18 & 25 & 25 & 60 & 18 & 68 & 18 \\
\hline LDH & $200-450 \mathrm{u}$ & 700 & 250 & 150 & 200 & 200 & 150 & 150 & 200 & 250 & 200 & 150 & 150 \\
\hline \multicolumn{2}{|l|}{$\begin{array}{l}\text { EMG_\% \% decrement } \\
\text { of evoked response }\end{array}$} & 75 & 68 & 50 & 0 & 50 & 34 & 32 & 10 & 69 & 25 & 22 & - \\
\hline \multicolumn{2}{|l|}{ EEG } & $\begin{array}{l}\text { Spk. } \\
+\end{array}$ & $\begin{array}{l}\text { Sl. } \\
\text { acty. } \\
+\end{array}$ & $\begin{array}{l}\text { Sl. } \\
\text { acty. } \\
++\end{array}$ & $\begin{array}{c}\text { Spk. } \\
+ \text { Si. } \\
\text { acty. + }\end{array}$ & $\begin{array}{l}\text { Sl. } \\
\text { acty. } \\
+\end{array}$ & Norm. & $\begin{array}{l}\text { S1. } \\
\text { acty. } \\
+\end{array}$ & $\begin{array}{l}\text { Sl. } \\
\text { acty. } \\
++\end{array}$ & $\begin{array}{c}\text { Sl. } \\
\text { acty. } \\
++\end{array}$ & Norm. & Norm. & $\begin{array}{l}\text { Sl. } \\
\text { acty. } \\
++\end{array}$ \\
\hline \multicolumn{2}{|l|}{$\begin{array}{l}\text { Muscle biopsy } \\
\text { Histology }\end{array}$} & $\begin{array}{c}\text { Fibre } \\
\text { abnorm. }\end{array}$ & - & $\begin{array}{c}\begin{array}{c}\text { Fibre } \\
\text { abnorm. }\end{array}\end{array}$ & Norm. & - & - & - & - & 一 & - & - & - \\
\hline $\begin{array}{l}\text { Glycogen } \\
\text { Phosphorylase }\end{array}$ & & $\begin{array}{l}\text { Inc. } \\
\text { Nil }\end{array}$ & $\overline{-}$ & $\begin{array}{l}\text { Inc. } \\
\text { Nil }\end{array}$ & $\begin{array}{l}\text { Norm. } \\
\text { Norm. }\end{array}$ & $\overline{-}$ & - & - & - & - & - & - & 二 \\
\hline
\end{tabular}

\section{DISCUSSION}

A further three cases of myophosphorylase deficiency have been confirmed in two interrelated families. Two sisters and their male cousin all showed the characteristic clinical features of the disease. The nine unaffected relatives who were also investigated showed no clear evidence of a heterozygous state with the tests employed. This is a rare disease and at the time of writing only 37 cases have previously been described in the English literature.

Several studies of affected families have shown evidence of consanguineous marriage between first cousins (Schmid and Hammaker, 1961; Rowland, Fahn, and Schotland, 1963; Rowland, Lovelace, Schotland, Araki, and Carmel, 1966). These studies have suggested that the disease has an autosomal recessive mode of inheritance. The genetic findings of the present study have confirmed the suggestion of a recessive inheritance, as the parents of the affected cases were apparently normal clinically and, in addition, other siblings were normal. It seems likely that inter- marriage has favoured the expression of the trait in the two families. It is of interest that only eight of the 37 cases previously described were female. If the condition is an autosomal recessive then males and females ought to be equally affected. However, the deviation of the observed from the expected values is highly significant $\left(\chi^{2}=10.81\right.$ and $\mathrm{P}$ approximately 0.001$)$. This marked male preponderance suggests the possibility of a sex-limited expression of an autosomal recessive character, although other explanations are also possible-for example, female homozygotes might be selectively eliminated over males during gestation. Classical X-linked re- 옹 cessive inheritance (for example, haemophilia) $D$ was not noted in this, or previous family studies.

An attempt to identify the heterozygous state $N$ by biochemical and muscle biopsy studies was not successful, although only one biopsy was performed on a clinically unaffected individual. Theoretically the parents of the affected cases should be carriers. A more extensive histochemical study of unaffected relatives (Bale, $\stackrel{\oplus}{\rightarrow}$ 
Hammett, and Neale, 1967) also failed to identify heterozygotes.

The 'second wind phenomenon' has been noted in other cases (Pearson, Rimer, and Mommaerts, 1961) and has been investigated in some detail by Pernow, Havel, and Jennings (1967) who concluded that 'second wind' could be correlated with the level of free fatty acid (FFA) of arterial blood, although they did not demonstrate increased mobilization of FFA into the blood in these patients. In addition they showed that 'second wind' was associated with procedures which increased muscular blood flow.

A trial of fenfluramine hydrochloride, a drug usually employed in the treatment of obesity, was given to one of the affected cases. This drug is thought to increase glucose uptake into muscle cells (Butterfield and Whichelow, 1968) and also to increase the serum FFA level (Pawan, 1969). However, no beneficial effect was noted. Yet all the affected cases obtained some relief by taking glucose or fructose before exercise, confirming the findings of other workers (Pearson et al., 1961).

In contrast with the patients described by Schmid and Hammaker (1961) the muscle symptoms were not progressing in the three patients described in this paper and no muscle wasting was apparent; in fact, the lower limb girdle muscles seemed particularly well developed, suggesting compensatory hypertrophy.

In the present investigation the affected cases showed minimal or no rise in serum lactate after ischaemic exercise. Several clinically unaffected relatives showed smaller rises than the controls, but the standardization of the test does not allow one to conclude that these are partially affected cases.

The raised levels of muscle enzymes at rest are consistent with some permanent damage to the muscle cell membrane, as suggested by Nixon, Hobbs, and Greenblatt (1966), and the changes in the muscle fibres seen on biopsy of case 1 would tend to confirm this.

The association of myophosphorylase deficiency with epilepsy has been noted previously and several theories have been propounded (Salmon and Turner, 1965). The epileptic threshold may be reduced by circulating breakdown products of muscle. Epilepsy may be precipitated by hypoglycaemia caused by the excessive blood glucose utilization on exercise, due to the failure of muscle glycogen breakdown. The muscle breakdown and myoglobinuria are precipitated during the anoxia in the muscle stress of an epileptic attack, the two conditions being unrelated. However, in our cases blood sugar studies were normal in all, and none showed myoglobinuria at any time; we therefore concluded that our abnormal EEG findings might reflect an increased epileptic tendency in the inter-related families or, alternatively, there is a possibility that an intraneuronal enzyme could be coded by the same genome as myophosphorylase-that is, the epileptic tendency may be a pleiotrophic phenomenon.

The normality of the electromyograms in the affected cases during normal conditions of rest and exercise is in keeping with the findings of other workers (Hockaday, Downey, and Mottram, 1964). Some observers have tended to believe that an electrically silent 'contracture' produced by exercise or evoked by repetitive stimulation of the motor nerve supply, is an invariable feature of this condition; this clearly is not the case. During the investigation of the families, the screening test described by Dyken, Smith, and Peake (1967) was used on the subjects, and also on a series of normal controls. The results show that the technique performed exactly as described by these workers does result in an appreciable drop in amplitude of the evoked response in normal subjects. A greater than $50 \%$ decrement in amplitude was not however seen in normal subjects with the exception of case 9 who showed a $69 \%$ decrement. The proposita and her clinically affected sister showed drops of $75 \%$ and $68 \%$ respectively, and the third affected patient, case 3, a $50 \%$ fall. There was therefore, no sharp division between normal and affected subjects.

\section{ADDENDUM}

Since this report was written, the proposita has married and has had a baby. Her normal progress in pregnancy and labour will be the subject of a further report.

We are indebted to Dr. C. St. Hill, Department of Pathology, Royal Southern Hospital, Liverpool, and 
Dr. W. H. Taylor, Department of Chemical Pathology, United Liverpool Hospitals, for allowing us to publish results obtained in their departments.

\section{REFERENCES}

Bale, P., Hammett, J. F., and Neale, F. C. (1967). Histopathology of McArdle's disease in a family. Journal of Pathology and Bacteriology, 94, 293-300.

Barker, S. B., and Summerson, W. H. (1941). The colorimetric determination of lactic acid in biological material. Journal of Biological Chemistry, 138, 535-554.

Butterfield, W. J. H., and Whichelow, M. J. (1968). Fenfluramine and muscle glucose uptake in man. Lancet, 2, 109.

Dyken, M. L., Smith, D. M., and Peake, R. L. (1967). An electromyographic diagnostic screening test in McArdle's disease and a case report. Neurology (Minneapolis), 17, 4550.

Hockaday, T. D. R., Downey, J. A., and Mottram, R. F. (1964). A case of McArdle's syndrome with a positive family history. Journal of Neurology, Neurosurgery, and Psychiatry, 27, 186-197.

Karmen, A., Wróblewski, F., and Ladue, J. S. (1955). Transaminase activity in human blood. Journal of Clinical Investigation, 34, 126-131.

King, J. (1959). A routine method for the estimation of lactate dehydrogenase activity. Journal of Medical Laboratory Techniques, 16, 265-272.

McArdle, B. (1951). Myopathy due to a defect in muscle glycogen breakdown. Clinical Science, 10, 13-35.

Mommaerts, W. F. H. M., Illingworth, B., Pearson, C. M., Guillory, R. H., and Seraydarian, K. (1959). A functional disorder of muscle associated with the absence of phosphorylase. Proceedings of the National Academy of Science, 45, 791-797.

Nixon, J. C., Hobbs, W. K., and Greenblatt, J. (1966). Myoglobinuria and skeletal muscle phosphorylase de- ficiency: report of a case of McArdle's disease. Journal of the Canadian Medical Association, 94, 977-985.

O'Brien, D., and Ibbott, F. A. (1962). Laboratory Manual of Pediatric Micro- and Ultramicro-Biochemical Techniques, p. 144. 3rd edition. Harper and Row: New York.

Pawan, G. L. S. (1969). Effect of fenfluramine on bloodlipids in man. Lancet, 1, 498-500.

Pearson, C. M., Rimer, D. G., and Mommaerts, W. F. H. M. (1961). A metabolic myopathy due to absence of muscle. phosphorylase. American Journal of Medicine, 30, 502-517.

Pernow, B., Havel, R. J., and Jennings, D. B. (1967). The $\stackrel{\text { ? }}{+}$ second wind phenomenon in McArdle's syndrome. Acta을 Medica Scandinavica, Suppl. 472, 294-307.

Rowland, L. P., Fahn, S., and Schotland, D. L. (1963). McArdle's disease. Hereditary myopathy due to absence of $\vec{\mathbb{}}$ muscle phosphorylase. Archives of Neurology, 9, 325-342.

Rowland, L. P., Lovelace, R. E., Schotland, D. L., Araki, S., and Carmel, P. (1966). The clinical diagnosis of McArdle's disease. Identification of another family with deficiency of $\vec{O}$ muscle phosphorylase. Neurology (Minneapolis), 16, 93- $\overrightarrow{\vec{H}}$ 100.

Salmon, S. E., and Turner, C. E. (1965). McArdle's disease presenting as convulsion and rhabdomyolysis. American Journal of Medicine, 39, 142-146.

Salter, R. H., Adamson, D. G., and Pearce, G. W. (1967). McArdle's syndrome (myophosphorylase deficiency). A ? study of a family. Quarterly Journal of Medicine, 36, 565- iv 578.

Schmid, R., and Mahler, R. (1959). Chronic progressive $\vec{V}$ myopathy with myoglobinuria. Demonstration of a음 glycogenolytic defect in the muscle. Journal of ClinieglInvestigation, 38, 2044-2058.

Schmid, R., and Hammaker, L. (1961). Hereditary absergeo of muscle phosphorylase (McArdle's syndrome). N New England Journal of Medicine, 264, 223-225.

Sutherland, E. W., and Wosilait, W. D. (1956). The relati ship of epinephrine and glucagon to liver phosphorylase. 1. Liver phosphorylase, preparation and properties. JournalO of Biological Chemistry, 218, 459-468. 